\title{
AFRICAN PENTECOSTALISM: THE CHRISTIANITY OF ELIAS LETWABA FROM EARLY YEARS UNTIL HIS DEATH IN 1959
}

\author{
Mookgo Solomon Kgatle ${ }^{1}$ \\ University of Pretoria
}

\begin{abstract}
An enormous body of research has been done on Pentecostal Christianity examining different branches such as classical, African and charismatic Pentecostalism. Most of these studies concentrate on classical Pentecostalism and western personalities. This article makes an important contribution to the ongoing research on Pentecostalism by studying African Pentecostalism, by looking at the life, calling and ministry of Elias Letwaba. The article argues that the Christianity of Elias Letwaba was an African Pentecostalism. In order to achieve this, the article studies the early life of Elias Letwaba to understand his family background. The article also establishes the fundamental teachings of African Pentecostalism and later compares them with the Christianity of Elias Letwaba. The purpose of this article is to demonstrate that Elias Letwaba was sanctified by faith; believed in the life of holiness; baptised in the Holy Spirit as evidenced by speaking in tongues; practised divine healing and founded a Bible College to teach these fundamental teachings of Pentecostalism.
\end{abstract}

Key Words: African Pentecostalism; Elias Letwaba; Healing; Patmos Bible College; Apostolic Faith Mission

\section{Introduction}

Elias Letwaba's father was a man who loved the Word of God. He lived in Middleburg, Transvaal. He was always in prayer and considered a little odd by others around him. His mother, on the other hand, was a nominal Christian. Things changed dramatically when six months before Letwaba was born his mother was grinding wheat. She suddenly saw a man clothed in white standing before her (De Wet 1989:65). The messenger said, "You will shortly have a strong baby boy. He is to be a messenger for me, to carry my Gospel message to many places. He will suffer much persecution and weariness, but I will be with him and protect him until his death, making him a means of blessing to thousands and an instrument in my hands for establishing many Christian churches" (Comforter 1959:8). The man disappeared and Letwaba's mother became a strong believer from that point forward.

Letwaba was born in the former Northern Transvaal (now Limpopo Province) around 1870, after his mother had received the remarkable revelation about his future. From the beginning of his life Letwaba was exposed to influences that were contrary to the normal upbringing of black people. His parents spoke Afrikaans in their home together with their native language Ndebele. This resulted in access to a much larger literature than was possible for other Ndebele speakers. Furthermore Letwaba was in constant contact with the

Dr Mookgo Solomon Kgatle is a research associate of Prof Dr Ernest van Eck in the Department of

New Testament Studies, University of Pretoria. 
children of the missionaries and his father, an Ndebele Christian, did not allow his son to attend the customary initiation school. Letwaba was therefore raised in a Christian environment (Comforter 1959:8). At the age of fourteen he rescued a man from drowning in a river and he felt called by God to rescue men and women out of the black river of sin and death (De Wet 1989:66).

At this time Letwaba received his first Bible from a White man for whom he worked as leader of a team of oxen (Lindsay 1972:41). In 1889 Letwaba joined the Berlin Lutheran Mission to train as a preacher. He learned German and read many books. During his lifetime like many other black South Africans, he became fluent in many languages, and was for the most part self-educated. At one point, when a visiting preacher came, Letwaba told his parents of his desire to preach the gospel. At nineteen years old Letwaba would tramp the villages with his twelve-year old brother, Wilfred, and preach wherever anyone would listen (De Wet 1989:67). He was unhappy to find out that the Berlin Lutheran Mission was a social club and sin was overlooked according to his perception. His heart longed for holiness, and he struggled with personal sin. In 1890 he switched to the Bapedi Lutherans, and stayed with them for nineteen years (Anderson 1996:125).

The article will first make describe African Pentecostalism. Secondly, the article discusses the fundamental teachings of African Pentecostalism, with the aim of demonstrating that Elias Letwaba was sanctified by faith; believed in the life of holiness; baptised in the Holy Spirit as evidenced by speaking in tongues; practised divine healing and founded a Bible College to teach these fundamental teachings of Pentecostalism.

\section{Description of African Pentecostalism}

Pentecostalism is based on the events as described in Acts 2:1-4 that when the day of Pentecost fully arrived, they were all with one accord in one place. Suddenly there came a sound from heaven like a rushing mighty wind, and it filled the entire house where they were sitting. There appeared unto them cloven tongues like fire, and it sat upon each of them. They were all filled with the Holy Ghost, and began to speak with other tongues, as the Spirit gave them utterance (Acts 2:1-4).

Pentecostalism has other characteristics such as faith healing, spirited music, certain theologies and a particular kind of piety, but speaking in tongues is the movement's most distinctive feature (Beckmann 1974:11). The essence of Pentecostalism is the baptism of the Holy Spirit and the gifts of the Spirit, especially the gift of speaking in tongues as the initial evidence of baptism in the Holy Spirit (Hocken 1976:83). In addition the Pentecostal Movement refers to that radical expression of Christianity which emphasises ecstatic speech in an unknown tongue as proof of the presence of the Holy Spirit (Tinney 1976:34). This Pentecostal experience, although not a new phenomenon, has attracted the attention of the world. Pentecostalism ultimately became the fastest growing stream of Christianity in both the United States and the rest of the world.

A characteristic of the Pentecostal Movement is an emphasis on charismata, above all, speaking in tongues (Holm 1991:136). Those who were influenced by the movement and the ones who began speaking in tongues normally joined a Pentecostal congregation. All Pentecostal churches throughout the world attach great importance to the 'baptism of the Holy Spirit' (Anderson \& Otwang 1993:114). The common ground among Pentecostals was that an authentic baptism of the Spirit was accompanied by a God-given sign of speaking in tongues (Randall 1997:64).Pentecostals were committed to a more explicitly supernatural form of baptism in the Holy Spirit. 
Furthermore the Pentecostal Movement teaches the gift of speaking in tongues as the initial and necessary evidence of baptism in the Holy Spirit (Roy 2000:120 cf. Westerlund 2009:7). Pentecostalism is a renewal movement within Christianity that places special emphasis on a direct personal experience of God (Anderson 2000:24). In this teaching a good starting point may be the central place given to the presence of the Holy Spirit, as experienced by the gifts of healing, speaking in tongues and prophecy; all of which have the human body as their locus (Droogers 2001:45 cf. Robbins 2004:117). This teaching and the experience of Spirit baptism has expanded the Pentecostal Movement from the United States to other regions (Onyinah 2004:218).

The Pentecostal Movement is built on the manifestation of spiritual gifts and purity (Fatokun 2005:159). The experience of Pentecostal spirituality is a hallmark of Pentecostalism. The Holy Spirit is personally and powerfully present to orchestrate the continuing redemptive ministry of Jesus Christ to the uttermost parts of the earth (Klaus 2007:41). The Pentecostal Movement, at least in its beginning, had a particular experience at its centre: baptism in the Spirit. It is also a movement of restoration that aspires to restore biblical Christianity (Andersson 2014:113).

The five major teachings of the Pentecostal Movement are:

- Justification by faith.

- Sanctification as a definite work of grace.

- Baptism in the Holy Spirit evidenced by speaking in tongues.

- Divine healing 'as in atonement'.

- The personal pre-millennial rapture of the saints at the second coming of Christ (Khathide 2010:62).

African Pentecostalism according to Kalu (2007:10) is not a movement that originated from and has been developed by external change agents, and dependent on transnational networks but an indigenous worldview, that answers questions raised from the interior of various African worldviews. African Pentecostal churches according to Ukah (2007:10) were significant in appropriating the Christian message in a distinctive way that attempted to provide locally meaningful answers to local questions and problems based primarily according to the perspective of the Bible as they understood it. Horn (2013:3) adds the four key characteristics: a mass popular base; a theology that focuses on and celebrates prosperity and accumulation of capital; a lack of regulation given the absence of a centralized religious authority; and the lack of a hermeneutic tradition and/or critical debate about Scripture.

African Pentecostalism is characterized by its focus on the supernatural. The belief in the supernatural is not degraded by modernism and natural science. African Pentecostalism is embedded in African maps of the universe. Pentecostals do not reject the spiritual forces perceived in traditional African religions. They rather redefine them, and engage in the struggle against them. African Pentecostals take the Bible very seriously. While Western Christians today tend to reject and redefine the biblical perceptions of reality, African Pentecostals take them for granted (Osthassel 2013:54). African Pentecostalism has proven relevant in responding to the challenging religious quest in the African heart. The Pentecostal emphasis on direct access to God through the Holy Spirit means for many of its African adherents, the ability to live the Christian life without recourse to the traditional ritual symbols that the older African Independent Churches' (AICs) incorporated into Christianity, and to which people continued to resort in the face of the staid, silent and cerebral Christianity of the mission churches (Asamoah-Gyadu 2013:409). 
African Pentecostal churches emerged as a radical expression of cultural resistance enabling Southern African blacks to mitigate the sufferings imposed by capitalism, colonialism and apartheid. African Pentecostal churches provided a dynamic Christianity that met African needs with a practice and theology of the Holy Spirit that is at the same time contextualised and biblical. In their emphasis on the power of the Spirit, African Pentecostals commemorate the most important element of the theological legacy of Lake. African Pentecostal churches also emphasise divine healing as the practical agency of divine force in the same manner as Lake did when he connected healing to the atonement. It is this message of liberation that makes the Pentecostal churches attractive to Africans. In Africa the most-powerful God is worshiped, and he manifests his presence through the Holy Spirit working in the church (Nel 2015:163).

African Pentecostalism can therefore be described as a part of Christianity in Africa that is influenced by: a Pentecostal Movement that started in the early church of the Apostles recorded in the book of Acts 2:1-4 and the Pentecostal Movement that started in the United States of America. In both influences, it is characterised by justification by faith, sanctification by grace, the baptism in the Holy Spirit evidenced by speaking in tongues, divine healing and the personal pre-millennial rapture of the saints at the second coming of Christ. In essence, it is a Pentecostal Christianity in an African context. The purpose of this article is to compare the Christianity of Elias Letwaba with the fundamental teachings of African Pentecostalism.

\section{The Christianity of Elias Letwaba}

\section{Justification by Faith and Sanctification by Grace}

Letwaba struggled with a sense of powerlessness and the teaching that focused on the traditions of men instead of the Word of God. There was a conviction in his life that there was more and he began crying out to God for His power of salvation to be made manifest. In his struggle he became ill and was close to death. Jesus appeared to him and called him to an open confession of his sin so that he would be healed. He was afraid of losing his reputation but he went to those against whom he had sinned first, and then to his wife and the missionaries with whom he worked to expose it all (Lindsay 1972:42).

\section{Baptism in the Holy Spirit}

Letwaba connected himself to the Zion Apostolic Church. He saw that the people had a living faith and he chose to be baptized by them. Still his heart was hungry for more. Letwaba went to one of the elders and explained, "I have fasted and cried many bitter tears. I have lain awake at nights, longing for holiness, and for the power of God, but the missionnaries with whom I work and the native preachers with whom I have associated only regard me as a crank, and laugh at me for my pains. Oh tell me, where can I find what I need?" The elder told him that John G Lake and Tom Hezmellhalch were preaching at the old Zulu Mission and that they should go and hear them. It is described that the meetings in Doorfontein in April 1908 were like a spiritual cyclone had hit the city, hundreds were healed and thousands were being saved. So great was the power of God on Lake that he would shake hands with someone entering the hall and they would fall to the ground under the power of the Spirit (De Wet 1989:68).

John G Lake invited Letwaba up onto the stage where he was preaching. This angered many of the white participants. Lake responded with, 'My friends, God has made of one blood all nations of men. If you do not want to acknowledge them as your brothers, then 
you'll have the mortification of going away into eternal woe, while you see many of these black folk going to eternal bliss.' Some whites suggested that the 'black devil' should be kicked out but Lake did not back down (Nel 2015:156).

Lake, however, refused to be cowed and kissed Letwaba and welcomed him into the meeting. People were threatening to throw Letwaba out when Lake said "If you throw him out then I will go out too." Letwaba's heart was melded to Lake's from that point. Letwaba followed Lake to his house where Lake shared his heart with him. Since Lake and Hezmellhalch were getting ready for Bloemfontein they invited Letwaba to go with them. On February 9, 1909 Letwaba was filled with the Holy Spirit. Letwaba travelled with the pair and was involved in their programmes (Anderson 1996:125 cf. Roy 2000:122).

Letwaba returned home and shared the good news of the baptism of the Holy Spirit with his father. His father immediately responded and was filled and began speaking in tongues. He also began an itinerant ministry of his own. He was beaten, stoned, kicked, and verbally and physically abused but he kept on going because there was a fire in his bones (De Wet 1989:68). Letwaba invited Lake to come to his home area of Potgietersrus. Lake and Hezmellhalch would visit for a few days at a time and all the men would minister together, seeing the sick healed. Letwaba felt a pressing desire for the party to go north to Zoutpansberg. They did so but several of the members caught malaria and two of the party died. Letwaba was broken-hearted as the men returned to the south but God called him to go back to the Northern Transvaal (Anderson 1996:126).

\section{Ministry in the AFM of South Africa}

Letwaba was one of the first black workers in the Apostolic Faith Mission (AFM) of South Africa, most of the time, for the meagre salary of five pounds per month. It is clear that Letwaba had a very strong following. Later, in 1921 Letwaba and DS Mokwena were appointed the first black marriage officers in the AFM by the government for the areas of Transvaal and the Free State respectively (Comforter 1921:13). Letwaba was overseer of the black district of Waterberg. Letwaba was also allowed to speak at white conferences by way of exception (De Wet 1989:71).

Letwaba and others in his day endured the harsh realities of South African racism. They continued to be humble even when these harsh realities found a way into the AFM of South Africa. Letwaba did not question the decisions made by the leadership of the church. It is this humble acceptance of the status quo that caused him to remain in the AFM for a long time (Anderson 1996:127). He was one of the highly gifted leaders whose contributions towards the growth of Pentecostalism went beyond the circles of the black community. Elias Letwaba stands out in the history of the Pentecostal Church in South Africa (Mathole 2005:184).

\section{Patmos Bible School}

,Recognizing Letwaba's leadership the AFM gave him the superintendence of the Zoutpansberg, Waterberg, and Middleberg native churches (De Wet 1989:65). Letwaba felt a growing need to have a school to train leaders. Often those who had heard the good news had little scriptural foundation and fell into error easily. He decided to open the 'Patmos Bible School' at Potgietersrus to address this need (Comforter 1930:7). It was built on faith in 1924 and completed without debt. It went on to include dormitories for the students and a school for children. The coursework was extensive and covered three years. Letwaba fed the students from his own home farm and small salary from the AFM. He trained his 
students extensively in the Bible but also included practical skills in speaking and deportment, as well as the English and Dutch languages (Erasmus 1996:25-42).

Letwaba's great desire was is to give his students a real grasp of the Bible, and before they left the school, his pupils were expected to be able to give a clear summary of the contents of every chapter in the Bible, a precis of every book, and to show a chapter and verse proof for the groundwork of each fundamental doctrine of the Word of God (Burton 1934:95).

His 'Black' Bible School paved the way for the development of a Pentecostal theological educational institute with its roots in Africa and his faith and determination made him the pioneer of theological education in the AFM, being the principal of the first AFM Bible School. On 3 February 1922, the Missionary Committee approved that Letwaba start a Bible school for the training of evangelists. They felt, however, that a central school was expected to materialize later (Erasmus 1996:25-42). In addition to the Patmos Bible School, a primary school with 150 pupils was also established next to the Bible School and some of the students in the Bible School were employed as teachers in the primary school.

Although it was not Letwaba's vision to create a racially divided Bible school, he followed the already segregated practice of the Church without questioning it, thereby endorsing the apartheid system by his silence (Nel 2014:112).

One of the highlights of Letwaba's achievements was the establishment in 1930 of the Patmos Bible School, the first theological training facility for Blacks in the Apostolic Faith Mission of South Africa (Roy 2000:122). Elias Letwaba was one of the first Black leaders of the AFM, a man whose ministry in the northern parts of the country led to the establishment of a large African church. Letwaba was a humble man who accepted the racial indignities imposed upon him by the White church leaders. His influence in the church was his powerfully charismatic evangelistic ministry, and the (mostly ignored) fact that it was his vision that established the first Bible School for the training of African pastors (Clark 2007:45).

In spite of political and economic difficulties Pastor Elias Letwaba, the Black overseer of Northern Transvaal, was able to fulfill Bible education without financial guarantees. His 'Black' Bible School paved the way for the development of a Pentecostal theological educational institute with roots in Africa. His faith and determination made him the pioneer of theological education in the AFM, being the principal of the first Bible School. In addition to the Patmos Bible School, a primary school with 150 pupils was established next to the Bible School (Burger \& Nel 2008:286).

\section{The Ministry of Divine Healing}

Letwaba's ministry was characterized by reported healings and miracles. It was these miracles that really opened the doors for him (Anderson 1996:127). On one occasion, which John G Lake afterwards related to William J Seymour in Los Angeles, it is testified that Letwaba was praying for a baby who had fallen and broken its neck. Lake went out of the room, as he did not have hope for a broken neck and did not want to interfere with Letwaba's faith. Letwaba carried on praying and the baby was healed (Lake 2011:32-33).

On another occasion he went to have meetings for the natives on a white man's farm. When he arrived there he was told to sleep in the chicken coop. He said, "Thank you, baas", made a broom from twigs, and cleaned the place and went to sleep. At midnight he was awakened by the farmer who said, "Wake up, Letwaba, my wife is desperately ill, come and pray for her." He got up immediately and prayed for the woman, who was healed instantaneously. The farmer then told him to go and sleep in an outside room, and apolo- 
gised for putting him in a chicken coop, but Letwaba said, "It is all right, sir, to put me there, my Master slept in a stable, and I am only a black worm" (Comforter 1959:7). For another two years Letwaba travelled, even going as far as Zimbabwe with his message. It is reported that during this time, more than ten thousand sick were permanently healed and over a hundred thousand souls were led to Christ (Lindsay 1972:51).

Letwaba began his ministry by walking hundreds of miles to visit remote villages. Everywhere he went he prayed for the sick and preached the gospel. One village he visited was in drought and all the animals were dying. The Holy Spirit came upon him and he declared, "I declare to you people, by the Word of God, that by this time tomorrow you shall have the rain you need. Your fields and your cattle shall be saved, and you will know that God still lives to answer the prayers of those who believe in Him." Letwaba spent the night in prayer and by the morning rain poured down upon the village (De Wet 1989:68). The village became open to Christ. Letwaba was an intercessor, often spending hours in prayer seeking God. In one case he was praying in a building that was being painted by unbelievers. They were mocking him, but the power of God hit the building and the entire building shook. They refused to work again until he had ended his time of prayer.

Embarking on an evangelistic tour of the Northern Transvaal, his home province, he walked many hundreds of miles, preaching the gospel of salvation, healing and baptism of the Holy Spirit (Roy 2000:122). Letwaba was responsible for thirty-seven churches. On Sundays he would lead services at five or six locations and would start at 5:30 in the morning and continue until 9:00 at night. He also taught six hours a day at the Bible school. He continued the school until 1935 when he was 65 years old. His congregations were tribally mixed, and often his sermons had to be given through two or three interpreters. He had a heart for holiness. He was a fervent preacher and saw healings and miracles in his ministry. He is often considered to be the man who received the mantle of Lake's healing ministry in South Africa. Letwaba died in 1959 at the age of 89 and was buried in the Waterberg district in the Northern Transvaal where he had spent most of his life and ministry (Anderson 1996:128).

\section{Conclusion}

The Christianity of Elias Letwaba is African Pentecostalism because he believed in justification by faith and sanctification by grace. Letwaba struggled with a sense of powerlessness and the teaching that focused on the traditions of men instead of the Word of God. Being convinced that there was more to life, he began crying out to God for His power of salvation to be made manifest. He believed in confession and the forgiveness of sins which comes by hearing the word of God. The breakthrough in Elias Letwaba's ministry was the result of his willingness to confess his sins and God forgave him.

Elias Letwaba's orientation was Pentecostal because he longed for the baptism of the Holy Spirit. Letwaba moved from one denomination to the other in search of the encounter and experience with the Holy Spirit. He moved from the Berlin Lutheran Mission to the Bapedi Lutherans Zion then the Apostolic Church but still struggled with a sense of. It was only when he met John G Lake on February 9, 1909 that Letwaba was gloriously filled with the Holy Spirit and was satisfied. Letwaba returned home and shared the good news of the baptism of the Holy Spirit with his father who also received the grace.

Furthermore his Christianity is Pentecostal because he believed and preached divine healing. Letwaba's ministry was characterized by reported healings and miracles. Elias Letwaba started a Bible School to teach the fundamental teachings of Pentecostalism. The students at Patmos Bible School were taught Justification by faith; Sanctification as a 
definite work of grace; Baptism in the Holy Spirit evidenced by speaking in tongues; Divine healing 'as in atonement' and the personal pre-millennial rapture of the saints at the second coming of Christ.

Letwaba was called for the work of ministry at a very tender age of fourteen. Since then, he never looked back and today he is considered to be one of the important leaders and trendsetters in the black Pentecostal movement in the AFM of South Africa. He preached a Pentecostal message of salvation, divine healing and the baptism in the Holy Spirit which is in line with the teaching of a Pentecostal Movement. He founded and led the 'Patmos Bible School' which also registered pupils in primary school. Despite all these accolades he remained humble and continued to serve the people. It is concluded therefore that the Christianity of Letwaba was African Pentecostalism.

\section{BIBLIOGRAPHY}

Anderson, A \& Otwang, S 1993. Tumelo: The Faith of African Pentecostals in South Africa, Unisa, Pretoria.

Anderson, A 1996. “African Pentecostalism”, St Hist Eccl 22(2):114-148.

Anderson, A 2000. Zion and Pentecost: The Spirituality and Experience of Pentecostal and Zionist/Apostolic Churches in South Africa, Unisa, Pretoria.

Andersson, G 2014. "To live the Biblical Narratives: Pentecostal Autobiographies and the Baptism in the Spirit", Pentecostudies 13(1):112-127.

Asamoah-Gyadu, JK 2005. ''Born of Water and the Spirit': Pentecostal/Charismatic

Christianity in Africa. African Christianity: An African Story”, pp. 388-409.

Beckmann, DM 1974. "Trance: From Africa to Pentecostalism", CTM 45(1):11-26.

Burger, I \& Nel, M 2008. The Fire Falls in Africa, Christian Art, Vereeniging.

Burton, WFP 1934. When God makes a Pastor, London: Victoria Press.

Clark, M 2007. "Contemporary Pentecostal Leadership: The Apostolic Faith Mission of South Africa”, Asian Journal of Pentecostal Studies 10(1):42-61.

Comforter, August 1921:13.

Comforter, January 1930:7.

Comforter, February 1933:10.

Comforter, June 1959.

Comforter, June 1959:8.

De Wet, CR 1989. "The Apostolic Faith Mission in Africa: 1908-1980. A case study in church growth in a Segregated Society", unpublished PhD Thesis, Department of Religious Studies, University of Cape Town.

Droogers, A 2001. "Globalization and Pentecostal Success" in Corten A \& Fratani RM, (eds.) Between Babel and Pentecost: Transnational Pentecostalism in Africa and Latin America, Hurst \& Company, London.

Erasmus, LJ 1996. "Theological Education in the Apostolic Faith Mission of South Africa, Unpublished doctoral thesis, Department of Practical Theology", Unisa, Pretoria.

Fatokun, SA 2005. Pentecostalism Globalization, Ogomoso, Journal of Theology, 10(4):159-170.

Hocken, P 1976. "The Significance and Potential of Pentecostalism”, in Hocken, P, Mills, JO, Tugwell, S \& Every G (eds.) New Heaven? New Earth? An Encounter with Pentecostalism, pp. 15-67, Templegate, Springfield, Illinois. 
Holm, NG 1991. "Pentecostalism: Conversion and Charismata", International Journal for the Psychology of Religion 1(3):135-151.

Horn, J 2013. Christian Fundamentalisms and Women's Rights in the African Context: Mapping the Terrain.

http://www.wluml.org/sites/wluml.org/files/Christian\%20Fundamentalisms\%20and $\% 20$ Women $\%$ E2\%80\%99s\%20Rights $\% 20$ in $\% 20$ the $\% 20$ African $\% 20$ Context Mapping\%20the\%20Terrain.pdf

Kalu, OU 2009. “A Discursive Interpretation of African Pentecostalism”, Fides et Historia, 41(1):71-90.

Khathide, AG 2010. Hamba Vangeli Elisha: A Portrait of Rev Job Y Chiliza-Pioneer of the African Gospel Church, Acad SA, Kempton Park.

Klaus, BD 2007. "Pentecostalism and Mission", Missiology: An International Review $1(1): 39-54$.

Lindsay, G 1972. John G Lake-Apostle to Africa, Christ for the Nations, Dallas, Texas,. Mathole, EMK 2005. "The Christian Witness in the Context of Poverty with special Reference to the South African Charismatic Evangelicals", PhD Thesis, Department of Science of Religion and Missiology, University of Pretoria.

Nel, M 2014. "A Hundred Years of Theological Training in the Apostolic Faith Mission of South Africa", Acta Theologica, 34(1):108-126.

Nel, M 2015. "Remembering and Commemorating the Theological Legacy of John G Lake in South Africa after a Hundred Years", Studia Historiae Ecclesiasticae, 41(3):147-170.

Onyinah, O 2004. "Pentecostalism and the African Diaspora: An Examination of the Mission Activities of the Church of Pentecost", Journal of the Society for Pentecostal Studies 26(2):216-241.

Østhassel, OA 2013. "Africa Pentecostalized? Understanding the African Appropriation of Pentecostalism in Light of African Perspectives", Doctoral Dissertation, MF Norwegian School of Theology.

Randall, IM 1997. "Old Time Power: Relationship between Pentecostalism and Evangelical Spirituality in England", Pneuma 19(1):53-80.

Robbins, J 2004. "The Globalization of Pentecostal and Charismatic Christianity", Annual Review of Anthropology 33(1):117-143.

Roy, K 2000. Zion City RSA: The Story of the Church in South Africa. South African Baptist Historical Society, Pretoria.

Tinney, JS 1976. "William J Seymour: Father of Modern-day Pentecostalism”, Journal of I.T.C 1(1):34-44.

Ukah, AF 2007. African Christianities: Features, Promises and Problems. Johannes Gutenberg-Universität, Bayreuth.

Westerlund, D (ed.) 2009. Global Pentecostalism: Encounters with Other Religious Traditions, IB Tauris, London. 